\title{
KAJIAN PRODUKTIVITAS TERNAK KAMBING PADA SISTEM PEMELIHARAAN YANG BERBEDA DI KECAMATAN ANDOOLO BARAT KABUPATEN KONAWE SELATAN
}

\author{
Masrah $^{1)}$, Harapin Hafid ${ }^{2)}$, Takdir Saili ${ }^{2)}$ \\ ${ }^{1)}$ Alumnus Fakultas Peternakan UHO \\ ${ }^{2)}$ Staf Pengajar Fakultas Peternakan UHO \\ e-mail: liongmasrah@yahoo.com
}

\begin{abstract}
ABSTRAK
Penelitian ini bertujuan untuk: (1) untuk mengevaluasi sebaran jenis ternak kambing yang dipelihara pada sistem yang berbeda, (2) untuk mengkaji tingkat produktivitas ternak kambing yang dipelihara pada sistem yang berbeda, (3) untuk mengkaji sistem pemeliharaan ternak kambing yang lebih produktif dan efisien di Kecamatan Andoolo Barat Kabupaten Konawe Selatan. Sampel pada penelitian ini adalah peternak kambing yang memelihara ternak kambing dengan sistem pemeliharaan yang berbeda. Metode yang digunakan pada penelitian ini adalah metode survey, wawancara dan observasi. Data yang diperoleh ditabulasi dan selanjutnya dianalisis dengan menggunakan metode deskriptif kuantitatif. Hasil penelitian adalah sebagai berikut: (1) sebaran populasi jenis ternak kambing yang dipelihara pada sistem pemeliharaan yang berbeda terdiri atas ternak kambing kacang 361 ekor, kambing PE 84 ekor, kambing Boer-PE 50 ekor dan kambing Boer-kacang 26 ekor. (2) bobot lahir anak kambing kacang jantan pada pemeliharaan secara ekstensif lebih tinggi $(1,83 \mathrm{~kg})$ dibandingkan anak kambing kacang betina $(1,69 \mathrm{~kg})$. Demikian halnya pada sistem pemeliharaan semi intensif dan intensif masing-masing anak kambing kacang jantan dan anak kambing kacang betina yaitu $2,32 \mathrm{~kg}$ vs $2,11 \mathrm{~kg}$ dan pemeliharaan intensif yaitu $2,51 \mathrm{~kg}$ vs $2,42 \mathrm{~kg}$. (3) bobot sapih yang tertinggi pada pemeliharaan secara ekstensif anak kambing kacang jantan lebih tinggi $(6.38 \mathrm{~kg})$ dibandingkan dengan anak kambing kacang betina $(6,28 \mathrm{~kg})$. Berdasarkan hasil tersebut disimpulkan bahwa (1) produktivitas ternak kambing seperti bobot lahir dan bobot sapih diperoleh pada sistem pemeliharaan secara intensif lebih baik dibandingkan dengan sistem pemeliharaan secara ekstensif dan semi intensif (2) sistem pemeliharaan secara intensif yang mampu menghasilkan produktivitas dan efisiensi usaha ternak kambing yang baik.
\end{abstract}

Kata kunci: kambing, produktivitas, intensif, semi intensif, ekstensif

\begin{abstract}
The objectives of this study were: (1) to evaluate distribution of goat population under different management production system, (2) to study goat productivity under different management production system, (3) to evaluate the best management production system of goat in Andoolo Barat, District of Konawe Selatan. The samples in this study were farmer who keeping goat under different management system. Survey, interview and observation were used as a method to collect the data in this study. Data collected were then tabulated and analyzed using descriptive quantitative method. The results showed that: (1) distribution of goat population under different production management system were consisted of 361 Kacang goat, 84 PE goat, 50 Boer-PE and 26 Boer-Kacang, (2) male Kacang goat under extensive production management system had higher birth weight $(1.83 \mathrm{~kg})$ compared to female Kacang goat $(1.69 \mathrm{~kg}$ ). The same cases were also observed in intensive and semi intensive production management system in which male birth weight of Kacang goat were higher than female (2.32 kg vs $2.11 \mathrm{~kg}$ and $2.51 \mathrm{~kg}$ vs $2.42 \mathrm{~kg}$, respectively), (3) male of Kacang goat had higher $(6.38 \mathrm{~kg})$ weaning weight compared to female of Kacang goat $(6.28 \mathrm{~kg})$ in extensive production management system. Based on the results it was concluded that (1) productivity of goat concerning to birth weight dan weaning weight in intensive production management system was better than extensive and semi intensive production management system, (2) Good productivity and efficiency of production of goat was gain under intensive production management system.
\end{abstract}

Keywords: goat, productivity, intensive, semi intensive, extensive 


\section{PENDAHULUAN}

Produktivitas ternak merupakan perkembangan populasi ternak dalam periode tertentu. Produktivitas ternak kambing dapat dilihat dari segi jumlah anak sekelahiran (litter size), bobot lahir, panen cempe, interval kelahiran dan mortalitas. Salah satu metode untuk meningkatkan produktivitas ternak kambing lokal yang hasilnya relatif cepat dan cukup memuaskan serta telah meluas dilaksanakan adalah dengan menyilangkan ternak kambing unggul, perbaikan tatalaksana pemberian pakan dan kontrol kesehatan. Persilangan itu sendiri adalah perkawinan antara kambing jantan dengan kambing betina dari rumpun yang berbeda.

Persilangan adalah upaya untuk meningkatkan produktivitas ternak kambing dengan perbaikan manajemen pemeliharaan serta pencegahan penyakit perlu ditingkatkan. Lazimnya dalam praktek terdapat tiga sistem pemeliharaan ternak kambing yang dilakukan oleh petani pada umumnya yaitu pemeliharaan secara ekstensif, semi intensif dan intensif. Hingga saat ini belum banyak terpublikasi kajian yang dilakukan untuk membandingkan tingkat produktivitas ternak kambing dari masing-masing sistem pemeliharaan ternak yang ada. Walaupun secara umum diyakini bahwa sistem pemeliharaan secara intensif dan semi intensif lebih baik dibandingkan dengan sistem pemeliharaan secara ekstensif.

Usaha peternakan kambing di Konawe Selatan cukup potensial untuk dikembangkan. Sebagai gambaran, saat ini populasi ternak kambing terus meningkat dari tahun ke tahun, khususnya dalam lima tahun terakhir ini. Pada tahun 2011 populasi ternak kambing di Kabupaten Konawe Selatan adalah 7.628 ekor dan pada tahun 2012 sebanyak 7.974 ekor dan pada tahun 2013 menjadi 8.089 ekor dan pada tahun 2014 populasi ternak kambing di Konawe Selatan adalah 9.506 ekor, pada tahun 2015 meningkat menjadi 10.076 ekor. Berdasarkan dinamika populasi dari tahun ke tahun yang cenderung mengalami peningkatan maka dapat disimpulkan sementara luas lahan yang potensial cenderung menurun dari tahun ke tahun, sehingga perlu ada kajian tingkat produktivitas ternak kambing (BPS Konawe Selatan, 2015).

Masyarakat di Konawe Selatan menerapkan berbagai sistem pemeliharaan seperti sistem ekstensif, semi intensif bahkan sudah ada beberapa anggota masyarakat yang menerapkan sistem pemeliharaan intensif. Namun demikian belum ada suatu kajian yang dapat memberi arahan tentang sistem pemeliharaan yang terbaik di Konawe Selatan untuk mendapatkan produktivitas dan efisiensi usaha yang baik. Oleh karena itu dibutuhkan suatu kajian tentang produktivitas ternak kambing pada sistem pemeliharaan yang berbeda.

\section{MATERI DAN METODE}

Penelitian ini dilaksanakan selama enam bulan yaitu pada bulan Juni November 2015, di Kecamatan Andoolo Barat, Kabupaten Konawe Selatan, Materi penelitian adalah ternak kambing, untuk melengkapi informasi dilakukan pula wawancara terhadap peternak kambing di lokasi penelitian. Alat-alat yang digunakan dalam penelitian ini adalah kandang, timbangan, parang, ember, baskom, skop, kamera, alat tulis dan lain-lain.

Metode penelitian yang digunakan dalam penelitan ini adalah metode survey dan pengamatan langsung. Metode penetapan lokasi penelitian adalah purposive sampling (Black dan Champion, 2001).

Teknik pengumpulan data dalam penelitian ini terbagi dua yaitu :

1. Wawancara, data yang dikumpulkan melalui wawancara adalah sistem pemeliharaan yang berbeda, system perkawinan, litter size, kidding interval, cid crop, morbiditas dan mortalitas.

2. Observasi dan pengukuran langsung terhadap ternak kambing yang diamati, 
data yang diambil melalui pengamatan langsung yaitu : bobot lahir dan bobot sapih.

Parameter penelitian:

a. Aspek produktivitas yang terdiri atas:

1. Bobot lahir diperoleh dengan cara menimbang bobot badan anak kambing yang baru lahir (umur 0 hari)

2. Bobot sapih diperoleh dengan cara menimbang bobot badan anak kambing pada saat disapih dari induknya (umur 90 hari)

3. Litter size diperoleh dengan cara menghitung jumlah anak yang lahir dari sejumlah induk yang melahirkan.
4. Kidding interval diperoleh dengan cara menghitung dari periode beranak sampai periode konsepsi.

5. Morbiditas diperoleh dengan cara menghitung jumlah ternak yang sakit dalam satu periode pemeliharaan.

6. Mortalitas diperoleh dengan cara menghitung jumlah ternak yang mati dalam satu periode pemeliharaan.

7. Kid Crop/panen cempe

Dihitung dengan melakukan pencatatan terhadap induk dan cempe yang lahir sampai dengan umur sapih (90 hari), dihitung dengan menggunakan rumus menurut Widi (2002):

Panen cempe $=\{($ Jumlah cempe lahir - Jumlah cempe mati $) \times 100 \%\} \times \underline{12}$

Jumlah induk

IK

Dimana $:$ IK = Interval Kelahiran

b. Aspek ekonomi yang terdiri dari;

1. Biaya investasi adalah biaya yang tidak habis dalam satu kali produksi. Biaya investasi terdiri atas : kandang, peralatan dan ternak kambing

2. Biaya operasional adalah biaya yang habis digunakan dalam satu kali proses produksi. Biaya operasional terdiri atas : pakan, obat-obatan dan tenaga kerja.

3. Penerimaan disebut juga pendapatan kotor, yaitu total hasil dikalikan harga pada saat itu.

4. Pendapatan adalah keuntungan yang diperoleh dalam satu periode, dengan rumus:

$$
\mathrm{NR}=\mathrm{TR}-\mathrm{TEC}
$$

Dimana :

$$
\begin{aligned}
\mathrm{NR}= & \text { pendapatan usaha ternak } \\
& \text { kambing } \\
\mathrm{TR}= & \text { total penerimaan usaha ternak } \\
& \text { kambing }
\end{aligned}
$$

$$
\begin{gathered}
\text { TEC }=\text { total biaya yang secara nyata } \\
\text { dikeluarkan }
\end{gathered}
$$

\section{Analisa Data}

Data yang diperoleh ditabulasi selanjutnya dianalisis secara deskriftif kuantitatif.

\section{HASIL DAN PEMBAHASAN}

\section{a. Bangsa Ternak Kambing yang Dipelihara}

Jumlah ternak kambing yang dipelihara oleh peternak berdasarkan bangsa dan sistem pemeliharaan di Kecamatan Andoolo Barat dapat dilihat pada Tabel 1. 
Tabel 1. Jumlah Ternak Kambing Berdasarkan Bangsa dan Sistem Pemeliharaan yang Berbeda di Kecamatan Andoolo Barat

\begin{tabular}{|c|c|c|c|c|c|c|}
\hline \multirow[b]{2}{*}{ No } & \multirow{2}{*}{$\begin{array}{l}\text { Bangsa } \\
\text { Kambing }\end{array}$} & \multicolumn{3}{|c|}{ Jumlah Ternak (Ekor) } & \multirow[b]{2}{*}{ Jumlah } & \multirow{2}{*}{$\begin{array}{c}\text { Persentase } \\
\%\end{array}$} \\
\hline & & Ekstensif & Semi Intensif & Intensif & & \\
\hline 1. & Kacang & 68 & 139 & 154 & 361 & 69,28 \\
\hline 2. & PE & 11 & 19 & 54 & 84 & 16,12 \\
\hline 3. & Boer-PE & 0 & 11 & 39 & 50 & 9,60 \\
\hline 4. & Boerka & 0 & 13 & 13 & 26 & 5,00 \\
\hline & Jumlah & 79 & 182 & 260 & 521 & 100 \\
\hline
\end{tabular}

Hasil penelitian menunjukkan bahwa jenis ternak kambing yang dipelihara diantaranya ternak kambing kacang, kambing PE, persilangan Boer-PE dan BoerKacang (Boerka). Pada pemeliharaan secara ekstensif sebanyak 79 ekor yaitu 68 ekor kambing kacang dan 11 ekor kambing PE, namun pada sistem pemeliharaan ekstensif tidak terdapat kambing Boer-PE dan kambing Boerka karena dilokasi penelitian yang memelihara kambing Boer-PE dan Boerka hanya pada pemeliharaan semi intensif dan Intensif. Kedua sistem ini memperoleh bibit ternak melalui program IB. Demikian halnya pada sistem pemeliharaan semi intensif dan intensif masing-masing sebanyak 182 ekor dan 260 ekor.

Tabel 6 menunjukkan bahwa populasi ternak yang tetinggi didaerah penelitian adalah ternak kambing kacang sebanyak 361 ekor, kambing PE 84 ekor, kambing persilangan Boer-PE 50 ekor dan kambing persilangan Boer-Kacang 26 ekor. Dari ketiga sistem pemeliharaan yang berbeda, pemeliharaan secara intensif yang memiliki populasi terbanyak dari 4 jenis bangsa ternak yang berbeda, adanya peningkatan ini dikarenakan sistem pemeliharaan intensif ternaknya dapat dikontrol pemeliharaannya, jika dibandingkan dengan pemeliharaan ekstensif yang sehari-harinya ternaknya dilepas berkeliaran kemana-mana sepanjang hari sedangkan pada pemeliharaan semi intensif ternaknya sewaktu-waktu dikandangkan dan selebihnya ternaknya digembalakan.

\section{b. Bobot Lahir}

Rataan bobot lahir ternak kambing berdasarkan bangsa dan sistem pemeliharaan yang berbeda dapat dilihat pada Tabel 2.

Tabel 2. Rataan Bobot Lahir (kg) Ternak Kambing pada Bangsa dan Sistem Pemeliharaan yang Berbeda di Kecamatan Andoolo Barat

\begin{tabular}{|c|c|c|c|c|c|c|c|c|c|}
\hline \multirow{3}{*}{ No } & \multirow{3}{*}{$\begin{array}{l}\text { Bangsa } \\
\text { Kambing }\end{array}$} & \multicolumn{6}{|c|}{ Bobot Lahir (Kg) } & & \\
\hline & & \multicolumn{2}{|c|}{ Ekstensif } & \multicolumn{2}{|c|}{ Semi Intensif } & \multicolumn{2}{|c|}{ Intensif } & \multicolumn{2}{|c|}{ Rata-Rata } \\
\hline & & $0^{\pi}$ & ㅇ & $0^{\pi}$ & ㅇ & $0^{\pi}$ & ㅇ & $0^{\pi}$ & 우 \\
\hline 1 & Kacang & 1,83 & 1,69 & 2,32 & 2,11 & 2,51 & 2,42 & 2,22 & 2,07 \\
\hline 2 & $\mathrm{PE}$ & 2,28 & 2,20 & 2,64 & 2,38 & 2,82 & 2,72 & 2,58 & 2,43 \\
\hline 3 & Boer-PE & 0,00 & 0,00 & 2,78 & 2,58 & 2,93 & 2,87 & 2,85 & 2,72 \\
\hline \multirow[t]{2}{*}{4} & Boerka & 0,00 & 0,00 & 2,52 & 2,28 & 2,66 & 2,57 & 2,59 & 2,42 \\
\hline & Rata-Rata & 2,05 & 1,94 & 2,56 & 2,33 & 2,73 & 2,64 & 2,56 & 2,41 \\
\hline
\end{tabular}


Hasil penelitian menunjukkan bobot lahir anak kambing kacang jantan pada pemeliharaan secara ekstensif lebih tinggi $(1,83 \mathrm{~kg})$ dibandingkan anak kambing kacang betina $(1,69 \mathrm{~kg})$. Demikian halnya pada sistem pemeliharaan semi intensif dan intensif masing-masing anak kambing kacang jantan dan anak kambing kacang betina yaitu $2,32 \mathrm{~kg}$ vs $2,11 \mathrm{~kg}$ dan pemeliharaan intensif yaitu $2,51 \mathrm{~kg}$ vs 2,42 $\mathrm{kg}$. Hal yang sama juga di dapatkan pada ternak kambing PE, pada sistem pemeliharaan ekstensif bobot lahir anak kambing PE jantan lebih tinggi dibandingkan anak kambing PE betina adalah 2,28 kg vs 2,20 kg. Demikian pula pada pemeliharaan semi intensif dan intensif masing-masing anak kambing PE jantan dan anak kambing PE betina yaitu 2,64 kg vs $2,38 \mathrm{~kg}$ dan $2,82 \mathrm{~kg}$ vs $2,72 \mathrm{~kg}$.

Bobot lahir anak kambing jantan Boer-PE pada pemeliharaan semi intensif lebih tinggi $(2,78 \mathrm{~kg})$ dibandingkan dengan anak kambing Boer-PE betina $(2,58 \mathrm{~kg})$. Demikian halnya pada pemeliharaan secara intensif masing-masing bobot lahir anak kambing Boer-PE jantan lebih tinggi dibandingkan dengan anak kambing BoerPE betina yaitu $2,93 \mathrm{~kg}$ dan $2,87 \mathrm{~kg}$. Hal yang sama di dapatkan pada kambing persilangan Boer dan kacang (Boerka) pada sistem pemeliharaan semi intensif dan intensif masing-masing bobot lahir anak kambing boerka jantan dan anak kambing boerka betina yaitu $2,52 \mathrm{~kg}$ vs $2,28 \mathrm{~kg}$ dan $2,66 \mathrm{~kg}$ vs $2,57 \mathrm{~kg}$.
Hasil penelitian menunjukkan peningkatan bobot lahir anak kambing kacang, PE, Boer-PE dan Boerka pada pemeliharaan secara intensif. Hasil ini tidak jauh berbeda dengan yang dilaporkan Elieser dkk (2006) rataan bobot lahir kambing kacang sebesar $(1,78 \mathrm{~kg})$ dan kambing boerka $(2,35 \mathrm{~kg})$. Demikian halnya bobot lahir anak kambing jantan lebih berat dibandingkan dengan anak kambing betina.Hasil ini sesuai yang dilaporkan Setiadi dkk. (2001)bobot lahir anak kambing jantan boerka 2,59 kg lebih tinggi di banding dengan anak kambing boerka betina 2,31 kg.

Menurunnya bobot lahir tersebut diakibatkan meningkatnya jumlah anak yang lahir perinduk, anak yang dilahirkan tunggal dapat menyerap makanan secara penuh dari induknya, sebaliknya pada kelahiran kembar akan terjadi persaingan dalam menyerap makanan dari induknya selama pertumbuhan embrio dalam uterus. Penurunan ini juga dapat diakibatkan dengan sistem pemeliharaan, dimana pemeliharaan secara ekstensif ternak dibiarkan mencari makanan sendiri sedangkan pada pemeliharaan intensif ternaknya diberi makan secara teratur dan pada pemeliharaan semi intensif ternaknya juga diberi makan dan sewaktuwaktu digembalakan.Hal ini terbukti dengan peningkatan bobot lahir yang cukup baik pada sistem pemeliharaan secara intensif.

\section{c. Bobot Sapih}

Rataan bobot sapih ternak kambing berdasarkan bangsa dan sistem pemeliharaan yang berbeda dapat dilihat pada Tabel 3 .

Tabel 3. Rataan Bobot Sapih (kg) Ternak Kambing pada Bangsa dan Sistem Pemeliharaan yang Berbeda di Kecamatan Andoolo Barat

\begin{tabular}{|c|c|c|c|c|c|c|c|c|c|}
\hline \multirow{3}{*}{ No } & \multirow{3}{*}{$\begin{array}{l}\text { Bangsa } \\
\text { Kambing }\end{array}$} & \multicolumn{6}{|c|}{ Bobot Sapih (Kg) } & \multirow{2}{*}{\multicolumn{2}{|c|}{ Rata-Rata }} \\
\hline & & \multicolumn{2}{|c|}{ Ekstensif } & \multicolumn{2}{|c|}{ Semi Intensif } & \multicolumn{2}{|c|}{ Intensif } & & \\
\hline & & $0^{\pi}$ & P & $0^{*}$ & ㅇ & $0^{\pi}$ & ㅇ & $0^{\pi}$ & q \\
\hline 1 & Kacang & 6,38 & 6,28 & 7,28 & 7,11 & 8,32 & 8,10 & 7,32 & 7,16 \\
\hline 2 & $\mathrm{PE}$ & 8,23 & 8,10 & 9,44 & 9,30 & 9,77 & 9,52 & 9,14 & 8,97 \\
\hline 3 & Boer-PE & 0,00 & 0,00 & 10,48 & 10,37 & 11,30 & 10,93 & 10,89 & 10,65 \\
\hline 4 & Boerka & 0,00 & 0,00 & 9,04 & 8,87 & 9,57 & 9,37 & 9,30 & 9,12 \\
\hline & Rata-Rata & 7,30 & 7,19 & 9,06 & 8,91 & 9,74 & 9,48 & 9,16 & 8,97 \\
\hline
\end{tabular}


Hasil penelitian tentang bobot sapih atau bobot hidup umur 90 hari dimana anak sudah dipisahkan dan tidak menyusu lagi dengan induknya, tersaji pada Tabel 10. Hasil penelitian ini menunjukkan bahwa bobot sapih pada pemeliharaan secara ekstensif anak kambing kacang jantan lebih tinggi $(6,38 \mathrm{~kg})$ dibandingkan dengan anak kambing kacang betina $(6,28 \mathrm{~kg})$. Demikian halnya pada sistem pemeliharaan secara semi intensif dan intensif masing-masing anak kambing kacang jantan dan betina yaitu $7,28 \mathrm{~kg}$ vs $7,11 \mathrm{~kg}$ dan $8,32 \mathrm{~kg}$ vs 8,10 kg. Hal yang sama juga di dapatkan pada kambing PE, Pada pemeliharaan ekstensif bobot sapih anak kambing PE jantan lebih tinggi dibandingkan anak kambing PE betina adalah $8,23 \mathrm{~kg}$ vs $8,10 \mathrm{~kg}$ sedangkan pada pemeliharaan semi intensif dan intensif adalah $9,44 \mathrm{~kg}$ vs $9,30 \mathrm{~kg}$ dan $9,77 \mathrm{~kg}$ vs $9,52 \mathrm{~kg}$.

Selanjutnya hasil penelitian yang diperoleh bobot sapih anak kambing BoerPE pada pemeliharaan semi intensif dan intensif masing-masing anak kambing jantan dan betina yaitu $10,48 \mathrm{~kg}$ vs $10,37 \mathrm{~kg}$ dan $11,30 \mathrm{~kg}$ vs $10,93 \mathrm{~kg}$. Hal yang sama juga didapatkan pada kambing Boerka, pada pemeliharaan semi intensif dan intensif bobot sapih anak kambing Boerka jantan dan betina masing-masing yaitu $9,04 \mathrm{~kg}$ vs $8,87 \mathrm{~kg}$ dan $9,57 \mathrm{~kg}$ vs 9,37 kg. Hasil penelitian yang diperoleh tidak jauh berbeda dengan hasil yang diperoleh Mahmilla dkk. (2007) yang menyatakan bahwa rataan bobot sapih kambing kacang (jantan 7,79 kg, betina $6,98 \mathrm{~kg}$ ) dan pada ternak kambing boerka $(7,68 \mathrm{~kg})$.

Hasil penelitian ini didukung oleh Erlangga dkk. (2013) yang menyatakan bahwa rata-rata bobot sapih yang diperoleh $10,58 \mathrm{~kg}$. dilihat dari dua sistem pemeliharaan menunjukkan adanya kecenderungan pada sistem penggembalaan lebih rendah dari pada sistem dikandangkan dengan rataan bobot sapih masing-masing $10,24 \mathrm{~kg}$ dan $10,46 \mathrm{~kg}$. Selanjutnya Elieser dkk. (2013) melaporkan bobot sapih kambing kacang sebesar 10,20 kg.
Adanya perbedaan bobot sapih yang diperoleh dari ketiga sistem pemeliharaan, ada kecenderungan bobot sapih yang dikandangkan/intensif lebih tinggi, hal ini dimungkinkan karena genetik dan sistem perkawinan. Bobot sapih juga banyak dipengaruhi oleh faktor lingkungan seperti pakan yang diberikan kepada cempe, sebab semakin tinggi kandungan nutrisi yang diberikan maka pada saat mencapai umur sapih ternak akan memperoleh bobot sapih yang maksimal. Hal ini sesuai dengan pendapat Maylinda, (2010) yang menyatakan bahwa perbedaan bobot sapih banyak dipengaruhi faktor lingkungan diantaranya manajemen pemeliharaan dan produksi susu induk. Selanjutnya Lu, (2002) menyatakan bahwa bobot sapih bervariasi tergantung pada pengaruh genetik, umur sapih, kesehatan serta manajemen pemeliharaan, terutama aspek pemberian pakan yang sangat berpengaruh terhadap kemampuan induk untuk memproduksi susu selama masa pertumbuhan pra sapih anak kambing.

\section{d. Morbiditas}

Jumlah morbiditas ternak kambing berdasarkan bangsa dan sistem pemeliharaan yang berbeda dapat dilihat pada Tabel 4 . 
Tabel 4. Morbiditas (ekor) Ternak Kambing pada Bangsa dan Sistem Pemeliharaan yang Berbeda di Kecamatan Andoolo Barat

\begin{tabular}{|c|c|c|c|c|c|c|c|c|c|c|}
\hline \multirow[b]{3}{*}{ No } & \multirow{3}{*}{$\begin{array}{l}\text { Bangsa } \\
\text { Kambing }\end{array}$} & \multirow{3}{*}{$\begin{array}{l}\text { Jumlah } \\
\text { Populasi }\end{array}$} & \multicolumn{6}{|c|}{ Morbiditas (Ekor) } & \multirow[b]{3}{*}{ Jumlah } & \multirow[b]{3}{*}{$(\%)$} \\
\hline & & & \multicolumn{2}{|c|}{ Ekstensif } & \multicolumn{2}{|c|}{ Semi Intensif } & \multicolumn{2}{|c|}{ Intensif } & & \\
\hline & & & Anak & Induk & Anak & Induk & Anak & Induk & & \\
\hline 1 & Kacang & 361 & 21 & 10 & 19 & 10 & 7 & 5 & 72 & 19,94 \\
\hline 2 & PE & 84 & 2 & 1 & 3 & 0 & 5 & 0 & 11 & 13,10 \\
\hline 3 & Boer-PE & 50 & 0 & 0 & 4 & 0 & 1 & 0 & 5 & 10,00 \\
\hline 4 & Boerka & 26 & 0 & 0 & 2 & 0 & 3 & 0 & 5 & 19,23 \\
\hline & Jumlah & 521 & 23 & 11 & 28 & 10 & 16 & 5 & 93 & \\
\hline
\end{tabular}

Berdasarkan hasil penelitian
menunjukkan bahwa angka kesakitan ternak kambing kacang pada pemeliharaan secara ekstensif adalah 31 ekor (21 ekor anak dan 10 ekor induk) lebih tinggi dibandingkan dengan pemeliharaan secara semi intensif 29 ekor (19 ekor anak dan 10 ekor induk) dan sistem pemeliharaan intensif adalah 12 ekor (7 ekor anak dan 5 ekor induk). Demikian halnya pada ternak kambing PE, pada berbagai sistem pemeliharaan. Pada sistem pemeliharaan ekstensif angka kesakitan ternak kambing PE adalah 3 ekor (2 ekor anak dan 1 ekor induk), pemeliharaan semi intensif 3 ekor anak dan intensif 5 ekor anak. Hal yang sama didapatkan pada ternak kambing Boer-PE dan Boerka pada pemeliharaan semi intensif dan intensif yaitu 4 ekor anak vs 1 ekor anak dan 2 ekor anak vs 3 ekor anak.

Tingkat kesakitan yang tinggi didapatkan pada pemeliharaan secara ekstensif. Hal ini kemungkinan disebabkan karena ternaknya dibiarkan merumput sepanjang hari, yang kemungkinan ternak tersebut merumput pada pagi hari, sebagaimana kita ketahui jika ternak merumput pada pagi hari larva cacing masih ada pada rumput. Dari hasil penelitian yang diperoleh angka sakit yang rendah pada pemeliharaan intensif, hal ini dimungkinkan pada pemeliharaan intensif ternaknya lebih terkontrol dalam pemeliharaannya sehingga kesehatan ternaknya dapat diperhatikan oleh peternaknya.

Adanya ternak yang sakit juga dimungkinkan dengan faktor cuaca seperti pada musim penghujan, dimana ternak yang dipelihara secara ekstensif akan mencari tempat berteduh, dalam hal ini tidak menjamin ternak akan terlindung dari cuaca dingin seperti ternak yang dikandangkan.

Seperti yang dijelaskan oleh Sarwono (2011) bahwa kambing akan tumbuh sehat bila suhu tubuhnya sekitar $39.5-40.5^{\circ} \mathrm{C}$, denyut jantungnya $70-80$ per menit, dan kecepatan bernapas 12-13 kali per menit. Tinggi rendahnya suhu tubuh sangat berkaitan dengan stress, aktivitas kegiatan, dan suhu lingkungan sekitarnya. Jika kambing menderita kaget, terlalu banyak bergerak atau berada di tempat yang panas dan lembab, suhu tubuhnya akan naik. Oleh karena itu, sebaiknya kambing dibiarkan dalam keadaan tenang agar suhu tubuhnya stabil.

\section{e. Mortalitas}

Mortalitas ternak kambing berdasarkan bangsa dan sistem pemeliharaan yang berbeda dapat dilihat pada Tabel 5 . 
Tabel 5. Mortalitas (ekor) Ternak Kambing pada Bangsa dan Sistem Pemeliharaan yang Berbeda di Kecamatan Andoolo Barat

\begin{tabular}{|c|c|c|c|c|c|c|c|c|c|c|}
\hline \multirow[b]{3}{*}{ No } & \multirow{3}{*}{$\begin{array}{l}\text { Bangsa } \\
\text { Kambing }\end{array}$} & \multirow{3}{*}{$\begin{array}{l}\text { Jumlah } \\
\text { Populasi }\end{array}$} & \multicolumn{6}{|c|}{ Mortalitas (Ekor) } & \multirow{3}{*}{ Jumlah } & \multirow{3}{*}{$(\%)$} \\
\hline & & & \multicolumn{2}{|c|}{ Ekstensif } & \multicolumn{2}{|c|}{ Semi Intensif } & \multicolumn{2}{|c|}{ Intensif } & & \\
\hline & & & Anak & Induk & Anak & Induk & Anak & Induk & & \\
\hline 1 & Kacang & 361 & 18 & 6 & 15 & 2 & 5 & 1 & 47 & 13,01 \\
\hline 2 & PE & 84 & 2 & 0 & 2 & 0 & 3 & 0 & 7 & 8,33 \\
\hline 3 & Boer-PE & 50 & 0 & 0 & 2 & 1 & 1 & 1 & 5 & 10,00 \\
\hline 4 & Boerka & 26 & 0 & 0 & 2 & 0 & 3 & 0 & 5 & 19,23 \\
\hline & Jumlah & 521 & 20 & 6 & 21 & 3 & 12 & 2 & 64 & \\
\hline
\end{tabular}

Hasil penelitian ini menunjukkan bahwa tingkat kematian kambing kacang pada sistem pemeliharaan secara ekstensif adalah 24 ekor (18 ekor anak dan 6 ekor induk) lebih tinggi dibandingkan dengan sistem pemeliharaan semi intensif yaitu 17 ekor (15 ekor anak dan 2 ekor induk) dan pada sistem pemeliharaan intensif adalah 6 ekor (5 ekor anak dan 1 ekor induk). Hal yang sama didapatkan pada ternak kambing PE dari berbagai sistem pemeliharaan. Pada sistem pemeliharaan ekstensif jumlah kematian kambing PE adalah 2 ekor anak, hasil ini sama dengan pada sistem pemeliharaan semi intensif yaitu 2 ekor anak dan sistem pemeliharaan intensif yaitu 3 ekor anak. Selanjutnya kematian pada ternak kambing Boer-PE hasil yang diperoleh adalah 2 ekor anak dan 1 ekor induk pada sistem pemeliharaan semi intensif dan sistem pemeliharaan intensif adalah 1 ekor anak dan 1 ekor induk. Hal yang sama didapatkan pada ternak kambing Boerka pada pemeliharaan semi intensif adalah 2 ekor anak dan sistem pemeliharaan intensif sebanyak 3 ekor anak. Penyebab kematian anak pada berbagai sistem pemeliharaan adalah kembung, kematian pada induk disebabkan oleh distocia dan prolapsus uterus.

Mortalitas prasapih umumnya sering terjadi pada anak kambing yang lahir kembar dari pada anak yang lahir tunggal. Hal ini kemungkinan disebabkan anak kambing yang lahir tunggal lebih mempunyai kesempatan untuk mendapatkan air susu dari induknya jika dibandingkan dengan anak kambing yang lahir kembar.

Adanya angka kematian yang tinggi ini kemungkinan karena induk bunting tua pada pemeliharaan ekstensif kurang mendapat asupan nutrisi, dengan sistem penggembalaan secara liar pakan yang diperoleh hanya rumput lapang saja, hal ini dianggap kurang karena pada pemeliharaan semi intensif dan intensif pakan yang diberikan cukup baik dalam segi kualitas.

Hasil penelitian ini didukung oleh Widaningsih dan Yuni, (2000) yang menyatakan bahwa jumlah kematian pada anak kambing dipengaruhi oleh beberapa faktor diantaranya adalah: induk kesulitan melahirkan, jumlah anak yang dilahirkan, sifat keindukan, faktor genetik, pengaruh iklim, bobot lahir anak, tatalaksana pemberian pakan, perawatan dan infeksi penyakit. Kondisi tersebut juga disebabkan oleh induk yang buruk pada saat bunting tua yang perlu asupan nurtisi yang cukup agar kondisi bunting tua dapat membantu pertumbuhan dan perkembangan janin. Pemberian asupan nutrisi yang cukup pada induk yang bunting tua juga menyebabkan anak yang dilahirkan kondisinya lebih sehat dan cepat dalam pertumbuhannya. Selanjutnya Setiadi dkk, (2001) menyatakan daya hidup pra sapih tergantung pada litter size produksi susu induk serta kemampuan induk dalam merawat anaknya selama periode menyusui. Pada kelahiran tunggal, kemampuan hidup anak lebih baik dari yang lainnya, karena memperoleh susu induk serta perhatian yang lebih baik. 


\section{f. Jarak Beranak (Kidding Interval)}

Rataan Kidding Interval ternak kambing berdasarkan bangsa dan sistem pemeliharaan yang berbeda dapat dilihat pada Tabel 6.

Tabel 6. Rataan Kidding Interval (bulan) Ternak Kambing pada Bangsa dan Sistem Pemeliharaan yang Berbeda di Kecamatan Andoolo Barat

\begin{tabular}{|c|c|c|c|c|c|}
\hline \multirow[b]{2}{*}{ No } & \multirow{2}{*}{$\begin{array}{l}\text { Bangsa } \\
\text { Kambing }\end{array}$} & \multicolumn{3}{|c|}{ Kidding Interval (Bulan) } & \multirow[b]{2}{*}{ Rata-Rata } \\
\hline & & Ekstensif & Semi Intensif & Intensif & \\
\hline 1. & Kacang & 8,07 & 7,00 & 7,00 & 7,35 \\
\hline 2. & $\mathrm{PE}$ & 7,50 & 7,00 & 7,00 & 7,16 \\
\hline 3. & Boer-PE & 0,00 & 6,00 & 6,00 & 6,00 \\
\hline \multirow[t]{2}{*}{4.} & Boerka & 0,00 & 6,00 & 6,00 & 6,00 \\
\hline & Rata-Rata & 7,78 & 6,50 & 6,50 & 6,62 \\
\hline
\end{tabular}

Hasil penelitian ini menunjukkan bahwa rataan interval kelahiran kambing kacang (8,07 bulan) pada sistem pemeliharaan secara ekstensif lebih tinggi dibandingkan dengan pemeliharaan semi intensif dan intensif yaitu 7,00 bulan vs 7,00 bulan. Hal yang sama interval kelahiran yang didapatkan pada ternak kambing PE pada pemeliharaan ekstensif yaitu (7,50 bulan) lebih tinggi dibandingkan dengan pemeliharaan semi intensif yaitu $(7,00$ bulan) dan pemeliharaan intensif $(7,00$ bulan).

Data Tabel 6 didapatkan interval kelahiran pada ternak kambing Boer-PE pada pemeliharaan semi intensif $(6,00$ bulan) sama dengan hasil yang diperoleh pada pemeliharaan intensif. Hal yang sama juga didapatkan pada ternak kambing Boerka yaitu $(6,00$ bulan $)$ baik pada pemeliharaan semi intensif maupun intensif.

Interval kelahiran adalah periode antara dua kelahiran yang berurutan, terdiri atas periode perkawinan dan periode bunting. Adanya perbedaan jarak kelahiran yang didapatkan dalam penelitian ini disebabkan oleh faktor jarak antara waktu induk beranak sampai induk dikawinkan kembali untuk pertama kali dan periode perkawinan ternak serta sistem pemeliharaan namun sejauh ini masih dalam kondisi yang normal, seperti yang dilaporkan oleh Garantjang (2004), menyatakan bahwa kidding interval kambing rata-rata 8-10 bulan.

Hasil penelitian ini didukung oleh Simon, Sumadi dan Subandrio (2012) yang melaporkan bahwa selang beranak kambing kacang adalah 8,2 bulan. Hal ini menunjukkan bahwa selang beranak yang tinggi akan mengakibatkan masa produksi yang semakin lama, ini disebabkan karena mayoritas peternak dilokasi penelitian tersebut mulai penyapihan pada umur 4-5 bulan.

\section{g. Litter size (jumlah anak sekelahiran)}

Rataan Litter size ternak kambing berdasarkan bangsa dan sistem pemeliharaan yang berbeda dapat dilihat pada Tabel 7 .

Tabel 7. Rataan Litter Size (ekor) Ternak Kambing pada Bangsa Kambing dan Sistem Pemeliharaan yang Berbeda di Kecamatan Andoolo Barat

\begin{tabular}{|c|c|c|c|c|c|}
\hline \multirow[b]{2}{*}{ No } & \multirow{2}{*}{$\begin{array}{l}\text { Bangsa } \\
\text { Kambing }\end{array}$} & \multicolumn{3}{|c|}{ Litter Size (Ekor) } & \multirow[b]{2}{*}{ Rata-Rata } \\
\hline & & Ekstensif & Semi Intensif & Intensif & \\
\hline 1. & Kacang & 1,60 & 2,00 & 2,00 & 1,86 \\
\hline 2. & $\mathrm{PE}$ & 1,75 & 2,00 & 1,53 & 1,76 \\
\hline 3. & Boer-PE & 0,00 & 1,75 & 1,50 & 1,62 \\
\hline 4. & Boerka & 0,00 & 1,80 & 1,88 & 1,84 \\
\hline & Rata-Rata & 1,67 & 1,88 & 1,72 & 1,77 \\
\hline
\end{tabular}


Hasil penelitian ini menunjukkan bahwa rataan litter size kambing kacang pada sistem pemeliharaan ekstensif adalah 1,60 ekor lebih rendah dibandingkan dengan sistem pemeliharaan semi intensif yaitu 2,00 ekor dan pemeliharaan intensif 2,00 ekor. Hal yang sama juga didapatkan pada kambing PE, pada sistem pemeliharaan ekstensif diperoleh 1,75 ekor dan pada pemeliharaan semi intensif 2,00 ekor jauh lebih tinggi yang didapatkan pada pemeliharaan intensif yaitu 1,53 ekor.

Selanjutnya litter size yang didapatkan pada ternak kambing Boer-PE pada pemeliharaan semi intensif yaitu 1,75 ekor lebih tinggi dibandingkan dengan pemeliharaan intensif yaitu 1,50 ekor. Demikian halnya pada ternak kambing Boerka, pada pemeliharaan semi intensif sebanyak 1,80 ekor lebih rendah dari pemeliharaan intensif yaitu 1,88 ekor.

Adanya perbedaan ini kemungkinan diakibatkan karena bobot induk dan umur induk kambing pada saat pertama kali dikawinkan, sebab bobot badan dan umur induk mempengaruhi litter size dan bobot anak yang dilahirkan. Hasil penelitian ini tidak jauh dengan penelitian Mahmilia (2007) yang mendapatkan litter size sebesar 1,31 ekor/kelahiran. Hal ini didukung oleh Sodiq dan Sadewo (2008) yang menyatakan bahwa litter size kambing sangat dipengaruhi oleh paritas dan ukuran badan induk. Postur tubuh induk akan mempengaruhi kemampuan induk dalam melahirkan jumlah anaknya. Induk dengan postur tubuh yang besar akan menghasilkan jumlah anak seperindukan yang lebih besar.

Hasil penelitian ini didukung oleh Kostaman dan Sutama (2007) yang menyatakan bahwa litter size seekor induk kambing ditentukan oleh tiga faktor yaitu: jumlah sel telur yang dihasilkan setiap birahi dan ovulasi, fertilisasi dan keadaan selama kebuntingan dan kematian embrio. Ketiga faktor tersebut tergantung dari umur induk, bobot badan induk, kambing pemacek, suhu lingkungan dan genetik tetua.

Secara genetik ternak kambing betina dapat melahirkan anak lebih dari 1 dalam 1 kali melahirkan (prolifik) terutama pada kelahiran kedua, ketiga dan seterusnya. Kejadian kelahiran lebih dari satu pada ternak kambing menunjukkan adanya tingkat kesuburan dan meningkatnya umur induk kambing. Litter size juga sangat menentukan laju peningkatan populasi ternak kambing, karena jumlah anak sekelahiran yang tinggi akan dapat mempengaruhi terhadap kenaikan populasi ternak kambing.

\section{h. Panen Cempe (Kid Crop)}

Panen Cempe (Kid Crop) ternak kambing berdasarkan bangsa kambing dan sistem pemeliharaan yang berbeda dapat dilihat pada Tabel 8.

Tabel 8. Panen Cempe/Kid Crop (\%) pada Bangsa Kambing dan Sistem Pemeliharaan yang Berbeda di Kecamatan Andoolo Barat

\begin{tabular}{clrccc}
\hline & Bangsa & \multicolumn{3}{c}{ Panen Cempe (\%) } & \\
\cline { 3 - 5 } No & Kambing & Ekstensif & Semi Intensif & Intensif & Rata-Rata \\
\hline 1 & Kacang & 49,56 & 125,71 & 240,00 & 138,42 \\
2 & PE & 200,00 & 240,00 & 228,57 & 222,85 \\
3 & Boer-PE & 0,00 & 280,00 & 250,00 & 265,00 \\
4 & Boerka & 0,00 & 280,00 & 250,00 & 265,00 \\
\hline & Rata-Rata & 124,78 & 231,42 & 242,14 & 222,81 \\
\hline
\end{tabular}

Hasil penelitian ini menunjukkan bahwa panen cempe ternak kambing kacang pada sistem pemeliharaan ekstensif $(49,56 \%)$ lebih rendah dibandingkan pada pemeliharaan semi intensif dan ekstensif yaitu $125,71 \%$ vs $240,00 \%$. Demikian halnya pada ternak kambing PE pada berbagai sistem pemeliharaan masingmasing yaitu 200,00\%, 240,00\% dan $228,57 \%$. Hal yang sama didapatkan pada 
ternak kambing Boer-PE dan Boerka pada pemeliharaan semi intensif yaitu $280,00 \%$ vs $280,00 \%$ dan pada sistem pemeliharaan intensif yaitu $250,00 \%$ vs $250,00 \%$.

Adanya perbedaan panen cempe pada sistem pemeliharaan dipengaruhi oleh mortalitas, litter size dan kidding interval, artinya semakin tinggi litter size maka semakin tinggi pula panen cempe yang diperoleh, sebaliknya semakin rendah mortalitas cempe prasapih akan meningkatkan angka panen cempe.

Hasil penelitian ini didukung oleh Aka (2008) yang mendapatkan angka panen cempe pada pemeliharaan sistem kandang kelompok sebesar $225,7 \%$ lebih tinggi dari pada panen cempe pada pemeliharaan kandang individu yaitu sebesar 176,6\%. Menurut Irawan (2006) panen cempe dapat digunakan sebagai salah satu indikator untuk menilai tingkat kesuburan populasi ternak kambing pada satu lokasi tertentu.

\section{KESIMPULAN}

Adapun kesimpulan dari penelitian ini adalah;

1. Jumlah populasi ternak kambing di kecamatan Andoolo Barat sebanyak 521 ekor yang tersebar di tiga desa, dan bangsa ternak kambing yang terbanyak di pelihara adalah kambing kacang.

2. Produktivitas bobot lahir dan bobot sapih ternak kambing pada sistem pemeliharaan intensif lebih tinggi dibandingkan dengan sistem pemeliharaan secara semi intensif maupun ekstensif. Sementara sistem semi intensif lebih tinggi dari sistem ekstensif.

3. Efisiensi usaha ternak kambing pada sistem pemeliharaan secara intensif lebih efisien dibandingkan dengan sistem pemeliharaan secara semi intensif maupun ekstensif. Sementara sistem semi intensif lebih efisien dari sistem ekstensif.

\section{DAFTAR PUSTAKA}

Aka, R. 2008. Produktivitas kambing Peranakan Etawah pada pola pemeliharaan sistem kandang kelompok dan kandang individu di Kecamatan Turi Kabupaten Sleman Provinsi DIY. Tesis Universitas Gadjah Mada. Yogyakarta.

Black, J.A, dan D.J. Champion. 2001. Metode dan Masalah Penelitian Sosial, Refika Aditama. Bandung.

BPS. 2015. Statistik Kabupaten Konawe Selatan.

Elieser, S. Sumadi dan Subandriyo. 2013. Productivity Comparison Between Boer and Kacang Goat Dam. Journal of The Tropical Animal Agriculture. Vol 37 (15-21).

Erlangga, B.A. Nasich.M. Nugroho dan Kuswati. 2013. Kacang Goats Doe Productivity in Kedungadem SubDistrict Bojonegoro Regency. Universitas Brawijaya. Malang.

Garantjang, G., 2004. Pertumbuhan Anak Kambing Kacang pada Berbagai Umur Induk yang Dipelihara Secara Tradisional. Jurnal Sains dan Teknologi. April 2004. Vol 4 no 1:40-45.

Irawan. M. 2006. Kinerja Induk dan Pertumbuhan Prasapih Anak kambing PE yang dipelihara di kelompok Ternak kambing PE Mandiri. Fakultas Peternakan. Universitas Gadjah Mada. Yogyakarta.

Kostaman, T dan Sutama I,K. 2007. Korelasi Bobot Badan Induk dengan Lama bunting, Litter Size, dan Bobot Lahir Anak Kambing Peranakan Etawah. Seminar Nasional teknologi Peternakan Veteriner: 522-527. Bogor.

Lu, C.D. 2002. Boer Goat Production: Progress and Perspective. Vice Chancellor of Academic Affairs, University of Hawai'i. Hilo, Hawai. 
Mahmilia, F. 2007. Penampilan Reproduksi kambing Induk: Boer dan Kacang yang Disilangkan dengan Pejantan Boer. Seminar Nasional Teknologi Peternakan dan Veteriner 2007: 485490.

Sarwono B. 2011. Beternak Kambing Unggul. Jakarta: Penebar Swadaya

Setiadi, B. Subandriyo, M. Martawidjaya, D.Priyanto, D. Yulistiani, T. Sartika, B. Tiesnamurti, K. Diwyanto dan L.Praharani 2001. Evaluasi Peningkatan Produktivitas Kambing
Persilangan. Kumpulan hasil-hasil penelitian Peternakan. APBN tahun anggaran 1999/2000. Balai Penelitian Peternakan.

Widaningsih dan Yani N. 2000. Kiat Menekan Kematian Anak Kambing dan Domba Periode Prasapih. Balai Penelitian Ternak. Bogor.

Widi, T.S.M, 2002. Kinerja Induk Kambing dan Domba Pada Tiga Zona Agro yang Berbeda. Universitas Gajah Mada, Yogyakarta 